\title{
Pengaruh media Quizizz terhadap kosa kata baku siswa kelas V sekolah dasar
}

\author{
Emi Febrina Ningrum
}

febrinaemi@gmail.com

SD Negeri Nogopuro, Sleman

\begin{abstract}
ABSTRAK
Penelitian ini dilatarbelakangi oleh rendahnya kosa kata baku siswa kelas $V$ sekolah dasar akibat masuknya bahasa "gaul" dan kurang efektifnya media pembelajaran yang digunakan untuk memperkenalkan kosa kata baku. Sementara itu, bahasa "gaul" berkembang melalui penuturan sehari-hari dan media teknologi. Penelitian ini bertujuan untuk mengetahui pengaruh media Quizizz terhadap kosa kata baku siswa kelas V sekolah dasar. Pelaksanaan penelitian ini menggunakan metode penelitian eksperimen dengan desain one group pretest posttest design. Jumlah sampel penelitian adalah 20 siswa kelas V SD Negeri Nogopuro yang dilakukan secara acak. Pengumpulan data yang digunakan adalah tes kosa kata baku sebagai data utama, sedangkan wawancara dan dokumentasi sebagai data pendukung. Data diuji dengan uji normalitas, karena data yang diperoleh berdistribusi normal maka dilakukan uji Paired Sample T Tes. Hasil uji Paired Sample T Test diketahui nilai Sig. (2-Tailed) adalah 0,000 $<0,05$, sedangkan hasil Mean Paired Differences adalah sebesar -37,95. Hal ini dapat disimpulkan bahwa terdapat pengaruh yang signifikan media Quizizz terhadap perbendaharaan kosakata baku siswa kelas V SD.
\end{abstract}

Kata kunci: media pembelajaran, Quizizz, kosa kata baku

\section{The Influence of Quizizz Media on Standard Vocabulary for $5^{\text {th }}$ Grade Elementary School Students}

\begin{abstract}
This research was conducted based on the lack of standard vocabulary competency of 5th grade elementary school students due to the current of globalization that continues to occur. The lack of standard vocabulary competency is the impact of the inclusion of slang that develops through and technological media. This study aimed to determine the effect of Quizizz media on the standard vocabulary of 5th grade elementary school students. The implementation of this research used an experimental research method with a one group pre-test post-test design. The number of research samples was 20 students of $5^{\text {th }}$ grade of Nogopuro Elementary School which was conducted randomly. The data collection used was a standard vocabulary test as the main data, while interviews and documentation is as supporting data. The data were tested by normality test, because the data obtained were normally distributed, the Paired Sample T Test was carried out. The results of the Paired Sample T Test are known to have the Sig value. (2Tailed) is $0.000<0.05$, while the Mean Paired Differences result is -37.95 . It can be concluded that there is a significant effect of Quizizz media on the standard vocabulary of 5th grade elementary school students.
\end{abstract}

Keywords: learning media, Quizizz, standard vocabulary 


\section{PENDAHULUAN}

Arus globalisasi terus mempengaruhi berbagai negara di Indonesia, termasuk di Indonesia. Globalisasi adalah berkembangnya sistem yang ada di dunia terhadap segala bidang kehidupan seluruh bangsa (Goldin \& Reinert, 2012). Globalisasi menjadikan hubungan setiap negara menjadi tanpa batas. Oleh karena itu, setiap negara harus mampu beradaptasi dan menentukan pemikiran yang tepat untuk menghadapi pesatnya arus globalisasi (Yuniarto, 2014).

Pengaruh arus globalisasi menuntut bangsa Indonesia untuk masuk dalam sistem budaya, sistem ekonomi, sistem pasar, dan sistem pengetahuan yang berkembang pada negara-negara di dunia (Istiarsono, 2014). Jika tidak mampu beradaptasi dengan baik, maka bangsa Indonesia akan tertinggal diantara negaranegara di dunia dan identitas bangsa akan hilang. Sudah semestinya generasi Indonesia harus dipersiapkan menjadi generasi yang tangguh baik dari segi intelektual, mental, maupun spiritual.

Globalisasi memberikan implikasi bahwa pola pendidikan di Indonesia harus berfokus pada penguatan identitas dan karakter bangsa. Terkait dengan hal tersebut, bahasa Indonesia memiliki peranan penting dalam penguatan identitas dan karakter bangsa. Dengan mencintai bahasa Indonesia juga berarti mencintai identitas negara Indonesia (Rustini \& Diarta, 2014). Selain sebagai identitas bangsa, bahasa Indonesia menjadi bagian dari sumber nilai-nilai sosial budaya yang mampu mengembangkan rasa kebangsaan (Setyaningsih et al., 2019).

Penggunaan literasi digital relevan dengan kebutuhan abad-21 yang menuntut setiap manusia terbuka dengan perkembangan teknologi. Pendidikan dituntut untuk segera melakukan gerakan literasi digital sebagai salah satu bentuk upaya mempersiapkan generasi Indonesia yang terkini dalam perkembangan teknologi namun tidak meninggalkan identitas bangsanya. Hal ini dilakukan agar generasi Indonesia tidak tergerus dengan arus globalisasi.

Selain berpengaruh terhadap kemampuan pada literasi digital bangsa Indonesia, globalisasi juga berpengaruh terhadap aspek penggunaan bahasa Indonesia. Bahasa adalah identitas suatu negara yang digunakan sebagai sarana interaksi dalam melakukan hubungan sosial antara satu orang dengan orang lainnya (Gustiasari, 2018). Bahasa Indonesia sebagai bahasa nasional bangsa Indonesia digunakan untuk berkomunikasi dalam kegiatan formal maupun nonformal. Baik dalam satu suku maupun antar suku. 
Dalam perkembangannya, pengaruh arus globalisasi tercermin pada perilaku bangsa Indonesia yang mulai meninggalkan bahasa Indonesia yang baik dan benar dan terbiasa menggunakan bahasa "gaul" (Sari, 2015). Bahasa gaul sering kali digunakan bukan hanya dalam komunikasi sehari-hari namun juga secara sengaja atau tidak disengaja juga digunakan dalam komunikasi formal. Hal ini yang menjadikan penggunaan bahasa Indonesia menjadi tidak baik dan tidak benar (Suminar, 2016).

Penggunaan bahasa Indonesia yang tidak baik dan tidak benar menyebabkan kedudukan bahasa Indonesia menjadi menurun. Pada hakikatnya bahasa Indonesia yang benar adalah penggunaan bahasa Indonesia yang sesuai dengan kaidah bahasa Indonesia. Kaidah bahasa Indonesia meliputi kaidah ejaan, pembentukan kata, kalimat, dan paragraf (Madina et al., 2019).

Salah satu bagian penting dalam penggunaan bahasa Indonesia yang baik dan benar adalah penggunaan kata baku dan tidak baku. Kata baku adalah kata yang sesuai dengan kaidah atau pedoman bahasa Indonesia (Ningrum, 2020). Kata baku pada umumnya digunakan dalam komunikasi resmi baik secara lisan maupun tulisan. Sementara itu, kata tidak baku adalah kata yang dalam penggunaannya tidak sesuai dengan kaidah atau pedoman bahasa Indonesia. Kata tidak baku muncul karena penulisan dan pengucapan yang salah dalam kehidupan sehari-hari (Rasuli, 2019).

Setelah dilakukan wawancara dan observasi terhadap siswa kelas V SD Negeri Nogopuro menunjukkan bahwa siswa kurang memahami penggunaan bahasa Indonesia yang baik dan benar. Siswa memiliki pengetahuan yang kurang terhadap perbedaan kosa kata baku dan tidak baku. Siswa sering menganggap bahwa beberapa kosa kata baku "aneh" karena tidak lazim digunakan dalam kehidupan sehari-hari. Akibatnya kata tidak baku yang biasa digunakan dalam kehidupan sehari-hari justru dianggap sebagai bahasa Indonesia yang benar bagi siswa.

Sementara itu, kosa kata baku merupakan bagian dari Kompetensi Dasar yang harus dibelajarkan di kelas V dan VI kurikulum SD. Dalam kenyataannya, berdasarkan hasil observasi di kelas V SD Negeri Nogopuro, guru hanya mengintegrasikan materi kosa kata baku langsung ke dalam sebuah teks. Tidak ada penekanan materi kosa kata baku tersendiri. Oleh karena itu diperlukan media pembelajaran yang secara cepat mendorong siswa untuk mampu menguasai kosa 
kata baku dalam jumlah banyak untuk selanjutnya dapat diaplikasikan oleh siswa baik dalam pembelajaran maupun kehidupan sehari-hari.

Dalam rangka memenuhi tuntutan literasi digital dan meningkatkan perbendaharaan kosa kata baku di kelas V SD Negeri Nogopuro, peneliti mencoba menggunakan Quizizz sebagai alternatif media pembelajaran. Quizizz merupakan media interaktif yang menyenangkan, menantang, dan menumbuhkan motivasi belajar bagi siswa. Penggunaan media Quizizz sebagai media pembelajaran bagi guru cukup mudah, sebab guru hanya diminta untuk mempersiapkan materi dalam bentuk pertanyaan dan alternatif jawaban dalam aplikasi ini (Aini, 2019).

Quizizz merupakan sebuah platform berbasis teknologi digital yang interaktif dan menarik bagi siswa. Apalagi pada pembelajaran dari rumah saat ini, penggunaan media berbasis teknologi menjadi bagian yang tidak terpisahkan dalam pembelajaran agar dapat berlangsung tidak membosankan dan memiliki hasil belajar yang maksimal (Kurniawan \& Huda, 2021). Selain itu, pemberian latihan dengan menggunakan media Quizizz membuat siswa lebih semangat dan termotivasi untuk belajar sehingga mampu meningkatkan pemahaman siswa (Annisa \& Erwin, 2021).

Hasil penelitian ini secara teoritis bermanfaat sebagai referensi dan kajian pengetahuan terkait pengaruh media Quizizz terhadap kosa kata baku siswa kelas 5 SD. Manfaat praktis bagi siswa adalah untuk meningkatkan kosa kata baku siswa dengan pembelajaran yang mudah, menyenangkan, dan bermakna. Kerangka pikir dalam penelitian ini adalah sebagai berikut.

\begin{tabular}{|c|}
\hline \begin{tabular}{c} 
Rendahnya kosa kata \\
baku siswa kelas V SD \\
Masuknya bahasa "gaul" \\
melalui globalisasi \\
\hline $\begin{array}{c}\text { Kurangnya penggunaan } \\
\text { media pembelajaran yang } \\
\text { tepat pada materi kosa } \\
\text { kata baku }\end{array}$
\end{tabular} \mid $\begin{array}{c}\text { Pengaruh media } \\
\text { Quizizz terhadap } \\
\text { kosa kata baku } \\
\text { siswa kelas V SD }\end{array}$ \\
\hline $\begin{array}{c}\text { Quizizz merupakan } \\
\text { media interaktif yang } \\
\text { menyenangkan, } \\
\text { menantang, dan } \\
\text { menumbuhkan motivasi } \\
\text { belajar bagi siswa. }\end{array}$ \\
$\begin{array}{c}\text { Quizizz mampu } \\
\text { meningkatkan ingatan } \\
\text { siswa terhadap materi } \\
\text { yang dipelajari }\end{array}$ \\
\hline
\end{tabular}

Gambar 1. Kerangka pikir

Hipotesis penelitian ini adalah terdapat pengaruh yang signifikan media Quizizz terhadap kosa kata baku siswa kelas V SD. Tujuan penelitian ini untuk 
mengetahui pengaruh media Quizizz terhadap perbendaharaan kosa kata baku siswa kelas V SD.

\section{METODE PENELITIAN}

\section{Jenis dan Desain Penelitian}

Metode penelitian yang digunakan adalah metode penelitian eksperimen. Metode penelitian eksperimen adalah metode penelitian yang digunakan untuk mencari pengaruh perlakuan tertentu terhadap yang lain dalam kondisi yang terkendalikan. Desain penelitian eksperimen yang digunakan adalah preexperimental design dengan jenis One-Group Pretest-Posttest Design. Desain ini dapat dilihat pada gambar berikut.

$$
\mathrm{O}_{1} \times \mathrm{O}_{2}
$$

\section{Gambar 2. Desain penelitian}

$O_{1} \quad=$ Pretest sebelum menggunakan Quizizz

$x \quad=$ Perlakuan (pembelajaran dengan menggunakan Quizizz)

$\mathrm{O}_{2} \quad=$ Postetest setelah menggunakan Quizz dalam pembelajaran

\section{Populasi dan Sampel Data}

Variabel dalam penelitian ini meliputi variabel bebas dan variabel terikat. Variabel bebas dalam penelitian ini adalah media Quizizz, sedangkan variabel terikatnya adalah kosa kata baku. Populasi dalam penelitian ini adalah siswa kelas 5A SD Negeri Nogopuro yang berjumlah 27 siswa. Penelitian ini menggunakan teknik Probablility Sampling dengan jenis teknik random sampling. Sampel dalam penelitian ini sebanyak 20 siswa terdiri atas 12 siswa laki-laki dan 8 siswa perempuan.

\section{Teknik dan Instrumen Pengumpulan Data Tes}

\section{Kosa Kata Baku}

Instrumen yang digunakan untuk mengetahui kosa kata baku siswa dalam penelitian ini adalah tes pilihan ganda dalam bentuk google form untuk pretest dan posttest. Instrumen pretest digunakan untuk mengetahui kondisi awal siswa, sedangkan instrumen postest digunakan untuk mengetahui efektivitas penggunaan 
Quizizz sebagai media permainan berbasis teknologi untuk meningkatkan perbendaharaan kosa kata baku siswa. Jumlah soal pretest dan posttest yang digunakan masing-masing sebanyak 50 butir soal. Siswa diminta untuk menentukan pilihan kata yang termasuk dalam kosa kata baku pada masing-masing butir soal.

Setelah dilakukan penyusunan instrumen pretest dan posttest, maka dilakukan uji validitas dan uji reliabilitas. Uji validitas dilakukan dengan menggunakan uji korelasi Bivariate Pearson. Hasil uji validitas menggunakan uji korelasi Bivariate Pearson menunjukkan bahwa $r$ hiting $\geq r$ tabel sebesar 0,2353 (dengan signifikansi 0,05). Hal ini menunjukkan bahwa instrumen pretest dan posttest dinyatakan valid. Uji reliabilitas menggunakan rumus Alpha Cronbach. Berdasarkan hasil Alpha Cronbach menunjukkan bahwa hasil reliabilitas 0,877>0,7 yang artinya reliabilitas kuat. Hasil Alpha Cronbach adalah sebagai berikut.

Tabel 1. Hasil uji reliabilitas

\begin{tabular}{|c|c|c|}
\hline $\begin{array}{c}\text { Cronbach's } \\
\text { Alpha }\end{array}$ & $\begin{array}{c}\text { Cronbach's Alpha Based on } \\
\text { Standardized Items }\end{array}$ & N of Items \\
\hline 0,877 & 0,865 & 50 \\
\hline
\end{tabular}

\section{Wawancara}

Wawancara yang digunakan sebagai data pendukung dalam penelitian ini adalah wawancara tidak terstruktur. Wawancara dilaksanakan sebelum dan setelah dilaksanakan pembelajaran dengan menggunakan media Quizizz. Wawancara dilaksanakan untuk mengetahui permasalahan siswa dalam menggunakan kosa kata baku dan respon siswa terhadap media Quizizz yang digunakan. Wawancara dilaksanakan kepada siswa kelas V SD Negeri Nogopuro.

\section{Dokumentasi}

Dokumentasi yang dilakukan adalah data hasil mencoba siswa dalam menggunakan Quizizz. Siswa diminta untuk mencoba permainan Quizizz berulang kali sampai memperoleh jumlah soal benar sebanyak 45 butir soal dari 50 butir soal yang disediakan.

\section{Teknik Analisis Data}

Analisis data yang digunakan dalam penelitian ini terdiri atas uji normalitas dan uji paired sample t-test.

1. Uji Normalitas 
Uji normalitas dilaksanakan dengan tujuan untuk mengetahui apakah data berdistribusi normal atau tidak. Hipotesis yang digunakan adalah H1: data berdistribusi normal, Ho : data tidak berdistribusi normal.

\section{Uji Paired Sample T-Test}

Analisis data dalam penelitian ini menggunakan Paired Sample T-Test. Paired Sample T-Test merupakan uji parametrik yang dapat digunakan pada dua data berpasangan. Tujuan dari uji ini adalah untuk melihat apakah ada perbedaan ratarata antara dua sampel yang saling berpasangan atau berhubungan, karena berpasangan maka data dari kedua sample harus memiliki jumlah yang sama atau berasal dari sumber yang sama.

Pedoman pengambilan keputusan dalam uji Sample T Test berdasarkan nilai siginikansi (Sig.) hasil output Paired Sample T Test adalah sebagai berikut.

1. Jika nilai Sig. (2-tailed) $<0,05$, maka Ho ditolak dan H1 diterima.

2. Jika nilai Sig (2-tailed) $>0,05$, maka Ho diterima dan H1 ditolak.

Selain menggunakan uji Paired Sample T Test, juga menggunakan selisih rerata hitung kelompok pretest dan posttest yang dapat dilihat dari tabel uji Paired Sample T-test.

\section{HASIL DAN PEMBAHASAN}

\section{Hasil Penelitian}

Pelaksanaan penelitian ini bertujuan untuk mengetahui pengaruh Quizizz terhadap perbendaharaan kosa kata baku di kelas V SD. Penelitian ini menghasilkan analalisis pengaruh Quizizz terhadap kosa kata baku kelas V SD. Metode penelitian yang digunakan adalah pre-experimental design dengan jenis One-Group PretestPosttest Design.

\section{Hasil Pretest}

Setelah dilakukan pretest untuk materi kosa kata baku dan tidak baku di SD Negeri Nogopuro diperoleh hasil bahwa dari 20 siswa kelas V yang digunakan sebagai sample diperoleh hasil rerata 51,3. Hal ini menunjukkan bahwa perbendaharaan kosa kata baku siswa kelas V SD Negeri Nogopuro masih rendah. Rendahnya perbendaharaan kosa kata baku siswa kelas V SD Negeri Nogopuro dipengaruhi oleh beberapa hal. Pertama, arus globalisasi menyebabkan mudah masuknya budaya negara lain. Kedua, masuknya bahasa gaul menyebabkan 
kaburnya bahasa Indonesia yang baik dan benar pada siswa. Ketiga, perkembangan teknologi yang pesat menjadikan munculnya berbagai bahasa tidak baku. Berdasarkan hal tersebut, sejalan dengan arus globalisasi maka dibutuhkan media pembelajaran yang menekankan pada literasi digital.

Dalam pelaksanaan penelitian ini diawali dengan pretest untuk mengetahui perbendaharaan kosa kata baku awal siswa sebelum dilaksanakan pembelajaran menggunakan media Quizizz. Pretest dilaksanakan secara daring menggunakan media google form dengan menggunakan 50 kosa kata baku dan tidak baku. Data hasil pretest adalah sebagai berikut.

Tabel 2. Hasil pretest siswa kelas $\mathrm{V}$

\begin{tabular}{|c|c|c|c|c|c|c|c|c|c|c|c|c|c|c|c|c|c|c|c|c|}
\hline No & 1 & 2 & 3 & 4 & 5 & 6 & 7 & 8 & 9 & 10 & 11 & 12 & 13 & 14 & 15 & 16 & 17 & 18 & 19 & 20 \\
\hline Pre & 36 & 76 & 36 & 70 & 60 & 46 & 46 & 52 & 56 & 38 & 40 & 44 & 52 & 64 & 50 & 38 & 84 & 48 & 38 & 52 \\
\hline
\end{tabular}

Jika dilihat dari data di atas terlihat bahwa 14 dari 20 siswa benar tidak lebih dari $50 \%$ dari soal yang ada, 2 siswa benar $80 \%$, 1 siswa benar 70\%, dan 3 siswa benar $60 \%$. Jika dilihat rata-ratanya, maka hasilnya adalah 51,3.

\section{Perlakuan}

Setelah dilakukan pretest untuk melihat kemampuan awal siswa sebelum menggunakan media Quizizz, selanjutnya dilakukan pembelajaran menggunakan media Quizizz. Sebelum melaksanakan pembelajaran menggunakan Quizizz, peneliti membuat akun Quizizz dan menginput soal. Setelah semua soal ter-input, peneliti mengatur permainan agar setiap siswa dapat melihat jawaban yang benar setelah memilih jawaban salah serta mengatur batas waktu pengerjaan Quizizz.

Pembelajaran dengan menggunakan media Quizizz dilaksanakan dengan memberikan permainan kosa kata baku dan tidak baku sebanyak tiga kali dengan masing-masing paket permainan sebanyak 50 kosa kata baku. Pembelajaran dengan media Quizizz ini dilaksanakan selama satu hari.

Setiap siswa pada setiap paket permainan diminta untuk mengulang secara terus menerus tanpa batasan sampai memperoleh soal benar paling sedikit sebanyak 45 dari 50 soal yang ada. Artinya, selama satu hari siswa akan menghafal kurang lebih 150 kosa kata baku. Berikut tampilan Quiziz yang digunakan. 


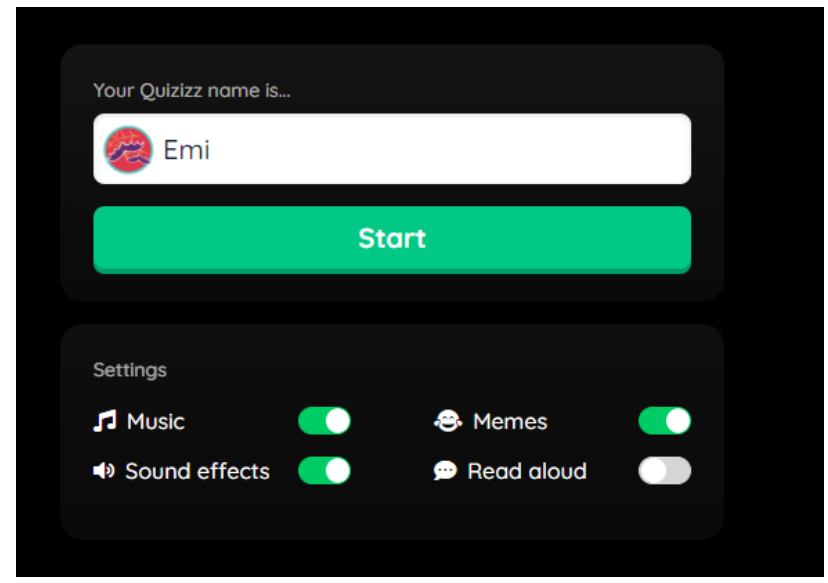

Gambar 1. Tampilan awal Quizizz siswa

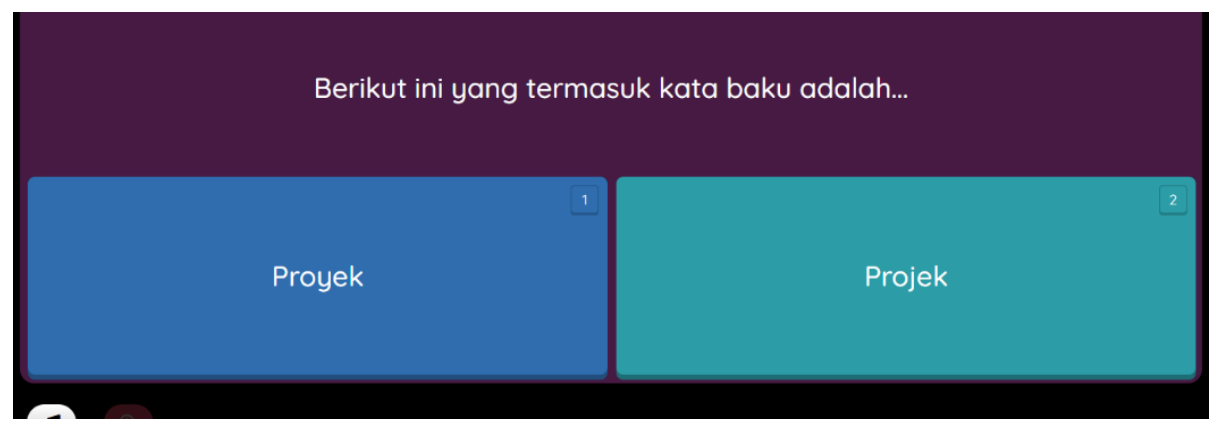

Gambar 2. Tampilan soal Quizizz siswa

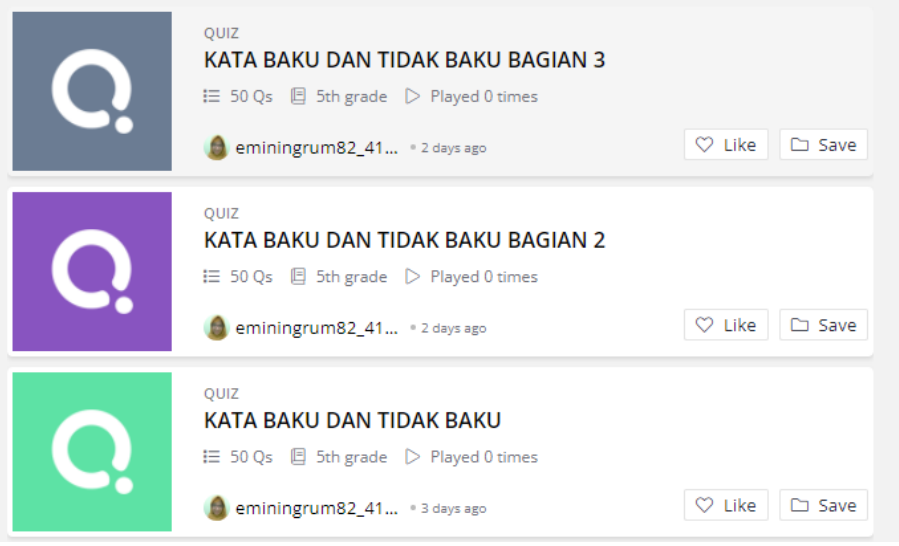

Gambar 3. Tampilan tiga paket soal yang digunakan

Pada Gambar 1 menunjukkan tampilan awal Quizizz siswa. Siswa diminta untuk mengisi identitas nama lengkap. Identitas siswa ini digunakan dalam rekap nilai permainan siswa pada admin Quizizz yang dipegang oleh peneliti.

Pada gambar 2 menunjukkan tampilan soal Quizizz siswa. Siswa akan menjawab setiap soal dengan memilih pada pilihan yang ada. Jika jawaban benar, tombol akan berwarna hijau, sedangkan jika jawaban salah maka tombol akan berwarna merah. Selain itu jika jawaban salah akan ditampilkan jawaban yang 
benar, sehingga siswa dapat belajar dari kesalahannya dan mengingat kosa kata baku yang benar. Setelah selesai menjawab 50 soal akan ditampilkan jumlah soal benar, jumlah poin, dan rentang waktu yang digunakan selama mengerjakan soal.

Pada gambar 3 menunjukkan tampilan tiga paket permainan Quizizz yang telah dibuat oleh peneliti. Pada setiap paket dapat dilihat rekap nilai setiap siswa yang diperoleh ketika bermain. Sehingga, media Quizizz ini dapat efektif dan efisien dalam memantau perkembangan belajar siswa.

Setelah mencapai jumlah jawaban benar paling sedikit 45 soal dari 50 soal yang ada, siswa diminta untuk menangkap layar hasil permainan dan melaporkannya kepada peneliti melalui google classroom. Melalui google classroom peneliti dengan mudah merekap siswa yang sudah berhasil menyelesaikan setiap permainan atau belum.

\section{Posttest}

Jika berdasarkan google classroom sudah dinyatakan siswa mengumpulkan tangkap layar permainan Quizizz dengan lengkap, maka peneliti melaksanakan posttest menggunakan media google form. Kosa kata baku dan tidak baku yang digunakan pada postest sebanyak 50 kata dengan waktu pengerjaan dibatasi. Posttest dilakukan untuk mengetahui apakah terjadi peningkatan kosa kata baku siswa kelas V SD atau tidak setelah dilaksanakan pembelajaran dengan menggunakan media Quizizz. Hasil posttest adalah sebagai berikut.

Tabel 3. Hasil posttest siswa kelas $\mathrm{V}$

\begin{tabular}{|c|c|c|c|c|c|c|c|c|c|c|c|c|c|c|c|c|c|c|c|c|}
\hline N0 & 1 & 2 & 3 & 4 & 5 & 6 & 7 & 8 & 9 & 0 & 1 & 2 & 3 & 4 & 5 & 6 & 7 & 8 & 9 & 0 \\
\hline & & 9 & 9 & 10 & 7 & 9 & 8 & 9 & 9 & 8 & 9 & 8 & 9 & 9 & 8 & 9 & 9 & 8 & 8 & 8 \\
Post & 90 & 4 & 2 & 0 & 6 & 8 & 8 & 0 & 2 & 0 & 4 & 6 & 0 & 4 & 0 & 4 & 2 & 5 & 6 & 4 \\
\hline
\end{tabular}

Tabel 2 tersebut menunjukkan hasil posttest siswa kelas V SD setelah menggunakan media Quizizz dalam pembelajaran. Sebanyak 4 siswa memperoleh jawaban benar sebanyak 80\%, 15 siswa memperoleh jawaban benar sebanyak 90\%, dan 1 siswa memperoleh jawaban benar sebanyak 100\%. Jika dihitung rata-ratanya adalah 89,25.

\section{Perbandingan Hasil Pretest dan Posttest}

Perbandingan hasil pretest dan posttest dapat dilihat pada tabel berikut ini. 
Tabel 4. Perbandingan pretest dan posttest siswa kelas $\mathrm{V}$

\begin{tabular}{|c|c|c|c|c|c|c|c|c|c|c|c|c|c|c|c|c|c|c|c|c|}
\hline N0 & 1 & 2 & 3 & 4 & 5 & 6 & 7 & 8 & 9 & $\begin{array}{l}1 \\
0\end{array}$ & 1 & 1 & $\begin{array}{l}1 \\
3\end{array}$ & $\begin{array}{l}1 \\
4\end{array}$ & $\begin{array}{l}1 \\
5\end{array}$ & $\begin{array}{l}1 \\
6\end{array}$ & $\begin{array}{l}1 \\
7\end{array}$ & $\begin{array}{l}1 \\
8 \\
\end{array}$ & $\begin{array}{l}1 \\
9\end{array}$ & $\begin{array}{l}2 \\
0\end{array}$ \\
\hline \multirow{2}{*}{ Pre } & 3 & 8 & 3 & \multirow{2}{*}{70} & 6 & \multirow{2}{*}{46} & \multirow[b]{2}{*}{46} & \multirow{2}{*}{52} & 5 & 3 & 4 & 4 & 5 & 6 & 5 & 3 & 8 & 4 & 3 & 5 \\
\hline & 6 & 0 & 6 & & 0 & & & & 6 & 8 & 0 & 4 & 2 & 4 & 0 & 8 & 4 & 8 & 8 & 2 \\
\hline \multirow{2}{*}{ Post } & 9 & 9 & 9 & 10 & 7 & \multirow{2}{*}{98} & \multirow{2}{*}{88} & \multirow{2}{*}{90} & 9 & 8 & 9 & 8 & 9 & 9 & 8 & 9 & 9 & 9 & 9 & 9 \\
\hline & 0 & 4 & 2 & 0 & 6 & & & & 2 & 0 & 4 & 6 & 0 & 4 & 0 & 4 & 2 & 4 & 2 & 2 \\
\hline Selisi & 5 & 1 & 5 & 30 & 1 & 52 & 42 & 38 & 3 & 4 & 5 & 4 & 3 & 3 & 3 & 5 & 8 & 4 & 5 & 4 \\
\hline h & 4 & 4 & 6 & & 6 & & & & 6 & 2 & 4 & 2 & 8 & 0 & 0 & 6 & & 6 & 4 & 0 \\
\hline
\end{tabular}

Jika dilihat pada tabel perbandingan pretest dan posttest tersebut, seluruh posttest siswa mengalami kenaikan dibandingkan dengan pretest. Hal ini menunjukkan bahwa media quizizz memiliki pengaruh yang signifikan terhadap kosa kata baku siswa kelas V SD.

\section{Hasil Uji Paired Sample T-Test}

Sebelum dilaksanakan Uji Paired Sample T-Test dilaksanakan Uji Normalitas dengan menggunakan Kolmogorov-Smirnov. Hasil uji normalitas dapat dilihat pada tabel berikut.

Tabel 5. Hasil uji normalitas

\begin{tabular}{|l|r|r|r|}
\hline \multirow{2}{*}{} & \multicolumn{3}{|c|}{ Kolmogorov-Smirnova } \\
\cline { 2 - 4 } & Statistic & \multicolumn{1}{c|}{ df } & \multicolumn{1}{c|}{ Sig. } \\
\hline Pretest & .180 & 20 & .090 \\
Postest & .148 & 20 & $.200^{*}$ \\
\hline
\end{tabular}

Hasil Uji Normalitas menunjukkan bahwa Signifikansi pada pretest adalah 0.09 > 0,05 , sedangkan pada posttest adlah $0,2>0,05$. Hal ini menunjukkan bahwa data berdistribusi normal.

Setelah data dinyatakan normal, maka dilaksanakan uji paired sample t-test. Hasil uji paired sample t-test ditunjukkan pada tabel berikut ini.

Tabel 6. Hasil paired sample statistics

\begin{tabular}{|ll|l|r|r|c|}
\hline & & & & \multicolumn{1}{c|}{$\begin{array}{c}\text { Std. Error } \\
\text { Mean }\end{array}$} \\
\hline Pair 1 & Pretest & 51.3000 & 20 & 13.64628 & 3.05140 \\
& Postest & 89.2500 & 20 & 6.16335 & 1.37817 \\
\hline
\end{tabular}

Jika dilihat pada tabel 6 tersebut, rata-rata hasi pretest adalah 51,5 sedangkan hasil posttest adalah 90,4 dari 20 siswa yang menjadi sample. Hasil ini terdapat perbedaan rata-rata yang signifikan antara hasil pretest dan posttest. 
Selain menggunakan rerata hitung, pengaruh media Quizizz terhadap kosa kata baku siswa juga dilihat dari hasil paired sample t-test. Hasil paired sample t-test dapat dilihat pada tabel berikut.

Tabel 7. Hasil paired samples test

\begin{tabular}{|c|c|c|c|c|c|c|c|c|}
\hline & \multicolumn{5}{|c|}{ Paired Differences } & \multirow[b]{3}{*}{$\mathbf{t}$} & \multirow[b]{3}{*}{ df } & \multirow{3}{*}{$\begin{array}{l}\text { Sig. (2- } \\
\text { tailed) }\end{array}$} \\
\hline & \multirow[b]{2}{*}{ Mean } & \multirow{2}{*}{$\begin{array}{c}\text { Std. } \\
\text { Deviati } \\
\text { on } \\
\end{array}$} & \multirow{2}{*}{$\begin{array}{l}\text { Std. } \\
\text { Error } \\
\text { Mean } \\
\end{array}$} & \multicolumn{2}{|c|}{$\begin{array}{c}95 \% \text { Confidence } \\
\text { Interval of the } \\
\text { Difference } \\
\end{array}$} & & & \\
\hline & & & & Lower & Upper & & & \\
\hline $\begin{array}{ll}\text { Pai } & \text { Pretest - } \\
\text { r } 1 & \text { Postest }\end{array}$ & $\begin{array}{r}- \\
37.95\end{array}$ & 13.612 & 3.0439 & -44.321 & -31.578 & -12.467 & 19 & .000 \\
\hline
\end{tabular}

Tabel 7 menunjukkan hasil Paired Sample T-Test. Pada tabel terlihat hasil selisih rerata antara hasil pretest dan posttest adalah 37,95. Hal ini menunjukkan terdapat pengaruh peningkatan kosa kata baku siswa kelas V SD secara signifikan.

Selanjutnya, pada tabel output Paired Sample T Test, diketahui nilai Sig. (2Tailed) adalah sebesar 0,000 $<0,05$, maka Ho ditolak dan H1 diterima. Sehingga dapat disimpulkan terdapat pengaruh yang sugnifikan perbendaharaan kosakata baku siswa kelas V SD setelah menggunakan media Quizizz dalam pembelajaran. Pengaruh ini berupa peningkatan yang signifikan perbendaharaan kosa kata baku siswa kelas V SD.

\section{Pembahasan}

Sebelum dilaksanakan pembelajaran dengan menggunakan media Quizizz siswa kurang memahami penggunaan bahasa Indonesia yang baik dan benar. Siswa memiliki pengetahuan yang kurang terhadap perbedaan kosa kata baku dan tidak baku. Siswa sering menganggap bahwa beberapa kosa kata baku tidak lazim digunakan dalam kehidupan sehari-hari. Akibatnya kata tidak baku yang biasa digunakan dalam kehidupan sehari-hari justru dianggap sebagai bahasa Indonesia yang benar bagi siswa.

Sementara itu, kosa kata baku merupakan bagian dari Kompetensi Dasar yang harus dibelajarkan di kelas V dan VI kurikulum SD. Dalam kenyataannya, berdasarkan hasil observasi di kelas V SD Negeri Nogopuro, guru hanya mengintegrasikan materi kosa kata baku langsung ke dalam sebuah teks. Tidak ada penekanan materi kosa kata baku tersendiri. Oleh karena itu diperlukan media 
pembelajaran yang secara cepat mendorong siswa untuk mampu menguasai kosa kata baku dalam jumlah banyak untuk selanjutnya dapat diaplikasikan oleh siswa baik dalam pembelajaran maupun kehidupan sehari-hari.

Sebelum dilaksanakan pembelajaran dengan Quizizz rata-rata hasil belajar kosa kata baku siswa adalah 51,3. Hal ini disebabkan oleh pengaruh globalisasi di Indonesia yang mulai menggeser Bahasa Indonesia yang baik dan benar dengan bahasa gaul. Selain itu juga karena kebiasaan berbahasa sehari-hari yang kurang tepat dalam masyarakat (Suminar, 2016).

Hasil pretest kosa kata baku yang relatif rendah juga dipengaruhi oleh kurangnya penggunaan media pembelajaran yang tepat untuk mengembangkan kosa kata baku siswa. Siswa hanya diberikan teks bacaan yang jumlahnya terbatas tanpa dijelaskan penggunaan kosa kata baku yang terdapat pada teks. Sementara itu, kosa kata baku jumlahnya sangat banyak dan bervariasi.

Berdasarkan hasil penelitian yang telah dilakukan, terjadi pengaruh yang signifikan penggunaan media Quizizz terhadap kosa kata baku siswa kelas V SD. Berdasarkan hasil wawancara dengan siswa juga Quizizz ini merupakan sebuah permainan yang menantang bagi siswa untuk terus mencoba. Ketika terjadi kesalahan dalam mengerjakan permainan, maka siswa akan tertantang untuk mecoba kembali dan belajar dari kesalahan sebelumnya. Secara tidak langsung siswa akan menghafal setiap kosa kata baku yang terdapat pada permainan. Dalam satu hari siswa mampu menghafal kurang lebih 150 kosa kata baku. Jika tidak menggunakan Quizizz siswa akan mengalami kejenuhan dalam menghafal kosa kata baku sebanyak itu.

Fitur umpan balik yang diberikan oleh Quizizz terdiri dari dua bagian utama: ringkasan permainan (skor dan peringkat), statistik kinerja (jumlah jawaban yang benar dan salah, jumlah pertanyaan yang tidak dicoba, dan waktu rata-rata per pertanyaan,. Siswa diberikan umpan balik semacam ini untuk mengidentifikasi kekuatan dan kelemahan mereka dalam hal pemahaman topik dan kinerja mereka selama mengikuti permainan. Siswa menggunakan umpan balik ringkasan permainan sebagai sumber informasi untuk menilai sendiri skor dan peringkat yang menandakan posisi siswa di antara siswa lain. Skor dan peringkat yang dicapai meningkatkan motivasi mereka untuk bermain lebih baik pada permainan berikutnya untuk mendapatkan peringkat yang lebih tinggi. Desain permainan mengembangkan hubungan antara pemain dan permainan yang mengarah pada peningkatan motivasi belajar lebih banyak lagi (Rahayu \& Purnawarman, 2018). 
Penggunaan Quizizz ini juga mudah untuk digunakan siswa. Siswa tidak perlu mengunduh aplikasi yang membuat membuat memori ponsel siswa penuh. Siswa cukup masuk pada link yang dikirim oleh guru, mengisi identitas, dan mengerjakan setiap butir soal yang ada. Bagi guru, aplikasi ini juga mudah digunakan karena guru tinggal memasukkan soal dan pilihan jawaban selanjutnya mengatur jadwal penugasan kepada siswa.

Penggunaan Quizizz sebagai bentuk latihan soal sesuai dengan karakteristik siswa saat ini. Bentuk tampilan yang disajikan pada permainan Quizizz berperan dalam membangun ingatan dalam pikiran siswa. Tampilan pada permainan Quizizz menstimulus otak kanan dalam pemrosesan informasi (Kurniawan \& Huda, 2021). Hal ini yang mempermudah siswa untuk cepat dalam mengingat kosa kata baku yang disajikan dalam permainan.

Permainan Quizizz menjadikan pengalaman latihan siswa menjadi menyenangkan, karena Quizziz menggunakan tampilan yang menarik disertai dengan gambar dan musik. Quizizz juga membantu siswa meninjau materi pelajaran dan merangsang minat siswa untuk terus belajar (Zhao, 2019).

Dalam proses belajar siswa, media Quizizz juga berpengaruh positif terhadap perhatian siswa, upaya memahami soal secara mandiri, keaktifan siswa dalam mengevaluasi dan mencatat materi, ketelitian dalam memahami soal dan manajemen waktu, serta ketenangan dalam mengerjakan soal (Salsabila et al., 2020). Jadi, media ini sesuai untuk meningkatkan proses dan hasil belajar siswa.

Media Quizizz juga berperan dalam salam satu tujuan komponen penutup pembelajaran yaitu mengingat kembali apa yang sudah siswa pelajari (Sukma et al., 2021). Sehingga, dengan media Quizizz ini pembalajaran menjadi lebih bermakna.

Selain itu, Quizizz juga sesuai dengan tugas perkembangan siswa kelas V SD yaitu mampu berpikir alternatif (Dina, 2020). Artinya, pada permainan Quizizz ini menyajikan alternatif jawaban yang memungkinkan siswa untuk berfikir dan mengahafal kosa kata baku dengan cepat.

\section{SIMPULAN}

Berdasarkan penelitian yang telah dilakukan menunjukkan hasil selisih rerata antara hasil pretest dan posttest adalah 37,95 . Hal ini menunjukkan terdapat pengaruh peningkatan kosa kata baku siswa kelas V SD secara signifikan. Selanjutnya, pada tabel output "Paired Sample T Test", diketahui nilai Sig. (2-Tailed) adalah sebesar $0,000<0,05$, maka Ho ditolak dan H1 diterima. Sehingga dapat 
disimpulkan terdapat pengaruh yang sugnifikan perbendaharaan kosakata baku siswa kelas V SD setelah menggunakan media Quizizz dalam pembelajaran. Pengaruh ini berupa peningkatan yang signifikan perbendaharaan kosakata baku siswa kelas V SD.

\section{UCAPAN TERIMA KASIH}

Terima kasih ditujukan kepada PGSD FKIP UNISSULA yang telah memberikan kesempatan untuk mempublikasikan artikel ini, serta SD Negeri Nogopuro sebagai tempat untuk melaksanakan penelitian ini.

\section{DAFTAR PUSTAKA}

Aini, Y. I. (2019). Pemanfaatan media pembelajaran jenjang pendidikan dasar dan menengah di Bengkulu. Kependidikan, 2(25), 1-6.

Annisa, R., \& Erwin, E. (2021). Pengaruh penggunaan aplikasi Quizizz terhadap hasil belajar IPA siswa di sekolah dasar. Jurnal Basicedu, 5(5), 3660-3667. https://doi.org/10.31004/basicedu.v5i5.1376

Dina, R. (2020). Analisis pencapaian tugas perkembangan siswa SD Negeri Serayu Yogyakarta. Jurnal Serunai Bimbingan Dan Konseling, 9(1), 1-6. https://doi.org/10.37755/jsbk.v9i1.279

Goldin, I., \& Reinert, K. (2012). Globalization for Development: Meeting New Challenges. Oxford University Press.

Gustiasari, D. R. (2018). Pengaruh perkembangan zaman terhadap pergeseran tata Bahasa Indonesia; Studi kasus pada pengguna instagram tahun 2018. Jurnal Renaissance, 3(2), 433-442. https://doi.org/10.53878/jr.v3i2.86

Istiarsono, Z. (2014). Tantangan pendidikan dalam era globalisasi: Kajian teoritik. Jurnal Intelegensia, 1(2), 19-24.

Kurniawan, M. C. D., \& Huda, M. M. (2021). Pengaruh penggunaan Quizizz sebagai latihan soal terhadap hasil belajar siswa kelas 5 SD. Jurnal Pena Karakter, 3(1), $37-41$.

Madina, L. ode, Pattiwael, M., Lahallo, F., Rupilele, F., \& Palilu, A. (2019). Penggunaan Bahasa Indonesia yang baik dan benar dalam berkomunikasi. Journal of Dedication to Papua Community, 2(2), 157-170. https://doi.org/10.34124/jpkm.v2i2.47

Ningrum, V. (2020). Penggunaan kata baku dan tidak baku di kalangan mahasiswa Universitas Pembangunan Nasional "Veteran" Yogyakarta. Jurnal Skripta, 5(2), 22-27. https://doi.org/10.31316/skripta.v5i2.398

Rahayu, I., \& Purnawarman, P. (2018). The use of Quizizz in improving students' grammar understanding through self-assessment. Eleventh Conference on Applied Linguistics (CONAPLIN 2018) , 104-114.

Rasuli. (2019). Meningkatkan hasil belajar Bahasa Indonesia materi kata baku dan tidak baku dengan media flash card pada siswa kelas VI SD N Sameye Tahun 2018/2019. Jurnal Ilmu Sosail Dan Pendidikan, 3(2), 334-340. https://doi.org/10.36312/jisip.v3i2.764

Rustini, N. K. P., \& Diarta, I. N. (2014). Menyikapi kebertahanan Bahasa Indonesia dalam menghadapi globalisasi di Bali. Jurnal Santiaji Pendidikan (JSP), 4(2), 126-129. https://doi.org/10.36733/jsp.v4i2.454 
Salsabila, U. H., Habiba, I. S., Amanah, I. L., Istiqomah, N. A., \& Difany, S. (2020). Pemanfaatan aplikasi Quizizz sebagai media pembelajaran ditengah pandemi pada siswa SMA. Jurnal IImiah Ilmu Terapan Universitas Jambi|JIITUJ/, 4(2), 163-173. https://doi.org/10.22437/jiituj.v4i2.11605

Sari, B. P. (2015). Dampak penggunaan bahasa gaul di kalangan remaja terhadap bahasa Indonesia. Seminar Nasional Bulan Bahasa UNIB 2015, 171-176.

Setyaningsih, R., Abdullah, A., Prihantoro, E., \& Hustinawaty, H. (2019). Model penguatan literasi digital melalui pemanfaatan e-learning. Jurnal ASPIKOM, 3(6), 1200-1214. https://doi.org/10.24329/aspikom.v3i6.333

Sukma, N., Lestari, P. I., \& Nur, R. A. (2021). Pengaruh media “Quizizz” dalam pembelajaran daring terhadap hasil belajar Biologi siswa. Binomial, 4(2), 154166. https://doi.org/10.46918/bn.v4i2.1042

Suminar, R. P. (2016). Pengaruh bahasa gaul terhadap penggunaan bahasa Indonesia mahasiswa Unswagati. Jurnal Logika, XVIII(3), 114-119.

Yuniarto, P. R. (2014). Masalah globalisasi di Indonesia: Antara kepentingan, kebijakan, dan tantangan. Jurnal Kajian Wilayah, 5(1), 67-95. https://doi.org/10.14203/jkw.v5i1.124

Zhao, F. (2019). Using Quizizz to integrate fun multiplayer activity in the accounting classroom. International Journal of Higher Education, 8(1), 37-43. https://doi.org/10.5430/ijhe.v8n1p37

Conflict of Interest Statement: The authors declare that the research was conducted in the absence of any commercial or financial relationships that could be constructed as a potential conflict of interest. 